Arq. Bras. Med. Vet. Zootec., v.67, n.5, p.1210-1216, 2015

\title{
Plasma PGFM and progesterone concentrations, luteolysis moment and estrous cycle length in Nelore cows submitted to uterine biopsies
}

\author{
[Concentrações plasmáticas de PGFM e progesterona, luteólise e comprimento do ciclo estral em \\ vacas Nelore submetidas à coleta de fragmentos endometriais] \\ I. Martin ${ }^{1}$, C.M.B. Membrive ${ }^{2}$, L.F. Vettorato ${ }^{3}$, M. Binelli ${ }^{4}$, E. Oba ${ }^{5}$, J.C.P. Ferreira ${ }^{5}$ \\ ${ }^{1}$ Universidade de Uberaba - Uniube - Uberaba, MG \\ ${ }^{2}$ Unesp - Dracena, SP \\ ${ }^{3}$ Veterinário autônomo \\ ${ }^{4}$ Faculdade de Medicina Veterinária e Zootecnia - USP - Pirassununga, SP \\ ${ }^{5}$ Faculdade de Medicina Veterinária - Unesp - Botucatu, SP
}

\begin{abstract}
In this study, endometrial samples were collected in 14 Nelore cows on days zero (ovulation), five, nine, thirteen and nineteen of the estrous cycle (biopsy group), and in 15 females these collections weren't performed (control group). Biopsies were done on the uterine horn endometrium contralateral to the ovary with corpus luteum. Blood samples were taken at $-24,-16,-8,0+8,+16$ and +24 hours in relation to progesterone drop $(<1 \mathrm{ng} / \mathrm{mL}$, zero moment) and evaluated for 13, 14-dihydro-15-keto prostaglandin F2-alpha (PGFM) by radioimmunoassay (RIA). Plasma progesterone concentration was determined by RIA every 24 hours. Data were analyzed by ANOVA using the PROC GLM and MIXED of the SAS. The mean value for PGFM during the entire period evaluated was greater in the biopsy group. The mean concentration of PGFM at moment zero was not different between the groups; the mean concentration of PGFM was higher in the biopsy group before and after the drop in progesterone level. The maximum mean concentration observed was not different between the groups; however, the mean minimum concentration was different with high values in the biopsy group. Although the PGFM concentrations were higher in the biopsy group, the biopsy and control groups had similar length of estrous cycle showing that repeated endometrial biopsy on the side contralateral to the ovary with corpus luteum does not affect luteolysis and the length of the estrous cycle.
\end{abstract}

Keywords: endometrium; bovine; 13, 14-dihydro-15-keto prostaglandin F2-alpha; progesteronic phase; corpus luteum

\section{RESUMO}

No presente estudo, foram coletadas amostras endometriais de 14 vacas Nelore nos dias zero (dia da ovulação), cinco, nove, 13 e 19 do ciclo estral (grupo controle), e em 15 fêmeas essas coletas não foram realizadas (grupo controle). As biópsias foram realizadas no corno uterino contralateral ao ovário contendo o corpo lúteo. Amostras plasmáticas foram coletadas nos momentos -24, -16, -8, $0+8,+16$ e +24 horas em relação à queda de progesterona $(<1 \mathrm{ng} / \mathrm{mL}$, momento zero) e avaliadas quanto à concentração de $13,14-d i-$ hidro-15-ceto prostaglandina F2-alpha (PGFM) por radioimunoensaio (RIA). As concentrações plasmáticas de progesterona foram avaliadas a cada 24 horas também por RIA. Os dados foram analisados por ANOVA empregando-se PROC GLM e MIXED do SAS. O valor médio de PGFM durante todo o período avaliado foi maior no grupo biópsia. A concentração média de PGFM no momento zero não diferiu entre os grupos, e foi maior no grupo biópsia antes e após a queda de progesterona. A concentração máxima observada não foi diferente entre os grupos, porém a concentração mínima diferiu com maiores valores observados no grupo biópsia. Embora as concentrações de PGFM fossem maior no grupo biópsia, ambos os grupos apresentaram o mesmo comprimento do ciclo estral, demonstrando que a coleta repetitiva de biópsias endometriais no corno uterino contraletral ao ovário contendo o corpo lúteo não afeta a luteólise e o comprimento do ciclo estral.

Palavras-chave: endométrio, bovino, 13, 14-di-hidro-15-ceto prostaglandina F2-alpha, fase progesterônica, corpo lúteo

Recebido em 25 de fevereiro de 2015

Aceito em 8 de junho de 2015

E-mail: ian.martin@uniube.br 


\section{INTRODUCTION}

Luteolysis is a physiological event that occurs between days 15 and 19 of the estrous cycle and is essential to determine the end of the luteal phase, growing of an ovulatory follicle and estrus. The release of endometrial prostaglandin F2-alpha (PGF2 $\alpha$ ) occurs in a pulsatile nature and is essential to induce luteolysis and regression of the corpus luteum (CL) (Okuda et al., 2002; Ginther et al., 2009). During the early luteal phase, $\mathrm{CL}$ is resistant, however mature $\mathrm{CL}$ becomes responsive to the luteolytic effect of PGF2 $\alpha$ (Miyamoto et al., 2005).

The release of PGF2 $\alpha$ occurs in response to binding of oxytocin to newly developed receptors in the uterine endometrium (Silvia et al., 1991; Mann et al., 1999). Homanics and Silvia (1988), Silvia et al. (1991) and Goff (2004) found that in bovine females oxytocin, progesterone and estradiol-17 $\beta$ act in regulating the pulsatile secretion of PGF $2 \alpha$.

PGF2 $\alpha$ reach CL through a counter current system between vena uterine and arteria ovarica (Shirasuna et al., 2004). In the systemic circulation, PGF $2 \alpha$ is inactivated into $13,14-$ dihydro-15-keto prostaglandin F2-alpha (PGFM) during the first passage through the lungs (Piper et al. 1970). Thus, the concentration of plasma PGFM is usually used to evaluate the release of endometrial PGF2 $\alpha$ secretion, once it has a longer half-life in peripheral circulation (Kindahl et al., 1976; Granström and Samuelsson, 1978; Kindahl et al., 1984; Mishra et al., 2003).

It has been observed that the occurrence of five to eight pulses of PGF $2 \alpha$ with a duration of 1 to 5 hours in a period of two to three days triggers luteolysis (Kindahl et al., 1976; Mann and Lamming, 2006; Ginther et al., 2007). During luteolysis, the PGFM pulses values range from 150 to $570 \mathrm{pg} / \mathrm{mL}$ (Kindahl et al., 1976; Kotwica et al., 1998).

The technique of endometrial biopsy is easy, and combined with a detailed history, rectal and vaginal examinations and microbial cultures, increases the success of the diagnosis, treatment and prognosis of uterine problems (Manspeaker and Bois, 1986). Chapwanya et al. (2010) showed that the use of endometrial biopsy sampling for clinical or research purposes is a safe and reliable technique and that these biopsies yielded intact endometrial tissue and nucleic acid suitable for histologic and molecular analysis.

According to Mann and Lamming (1994), endometrial sample collection between days 13 and 17 after estrus did not reduce the duration of the estrous cycle and the release of PGF $2 \alpha$. Thus, this technique can be applied to obtain endometrial tissue for studying the physiology of the estrous cycle.

Then, the hypothesis of this study was that the endometrial biopsy could be done throughout the estrous cycle without effects on the concentrations of PGFM and luteolysis. The aim of the present study was to determine if collecting endometrial biopsies throughout the estrous cycle alters the length of the estrous cycle, and plasma concentration of PGFM and progesterone compared to cows not subjected to endometrial biopsy.

\section{MATERIALS AND METHODS}

The experimental protocol (59/2002-CEEA) was approved by the Animal Welfare and Ethics Committee of the Veterinary Medicine and Animal Science College, São Paulo State University, SP, Brazil.

Twenty-nine cycling Nelore cows, at least 60 days postpartum, 3 to 14 years of age $(6.6 \pm 0.8$, mean \pm standard error, S.E.) and presenting body score $\geq 3$, on a scale of 0 to 5 , were used. Animals were fed grass, supplemented with hay and concentrate twice daily and had access to mineral supplement and water ad libitum.

For estrus synchronization, cows were synchronized according to Barros et al. (2000). Briefly, cows were treated i.m. with $25 \mu \mathrm{g}$ of GnRH (Gestran Plus ${ }^{\circledR}$, Lecirelina, Tecnopec, Brazil) on the first day, followed by i.m. administration of $15 \mathrm{mg}$ of prostaglandin seven days later (Preloban ${ }^{\circledR}$, D-Cloprostenol, Intervet, Brazil). After that, ovaries were examined daily by rectal palpation and ultrasonography (Aloka SSD 500, Aloka Co. Ltd., Japan, with a 5.0 MHz transducer) to determine the day of ovulation (Day 0).

After ovulation, the animals were randomly divided into two groups: biopsy group $(n=14)$ and control group $(\mathrm{n}=15)$ and were subjected to 
ultrasonography daily throughout one estrous cycle. Fifteen days after ovulation, jugular blood samples were collected in heparinized tubes by venipuncture every 8 hours until the next ovulation. Blood samples were centrifuged at 2500x g for 15 minutes and the plasma harvested and stored at $-20^{\circ} \mathrm{C}$ for later measurement of plasma progesterone and PGFM.

Endometrial biopsies were performed transcervically using a Yomann biopsy nipper (Hauptner, Solingen, Germany). The collection of endometrial tissue was performed in the uterine horn contra-lateral to the ovary with the corpus luteum. Biopsies were taken on D0, D5, D9, D13 and D19 of the estrous cycle. During the biopsy, a single endometrial fragment approximately 4 to $5 \mathrm{~mm}$ in diameter was removed. All the samples were collected by the same person who was trained and experienced in the technique.

Hormonal assays were performed by radioimmunoassay technique. Concentrations of progesterone were measured in plasma samples in duplicate using a Count-A-Count kit (Diagnostics Products Corporation, Los Angeles, CA, USA) according to the manufacturer's instructions. Five assays were performed and intra-assay coefficient of variation was $8.28 \%$ and the inter-assay coefficient of variation was $10.39 \%$.

After the determination of plasma progesterone concentration, samples from the 24 hours before (moments -24, -16, -8) and 24 hours after $(+8$, +16 and +24$)$ progesterone drop $(<1 \mathrm{ng} / \mathrm{mL}$, which was considered the zero moment or the luteolysis day) were selected for the PGFM (the principle metabolite of PGF2 $\alpha$ ) measurement by the radioimmunoassay (RIA) technique, which was previously validated for bovine species in Molecular Endocrinology and Physiology Laboratory (LFEM) at the College of Veterinary Medicine and Animal Science - Sao Paulo University. All samples were analyzed in duplicate and intra-assay coefficients of variation were $1.37 \%, 2.71 \%$ and $11.28 \%$ and inter-assay coefficients of variation were $1.40 \%, 2.30 \%$ and $3.43 \%$ for references with 50, 500 and $1000 \mathrm{pg} / \mathrm{mL}$ of PGFM, respectively.

For statistical analysis, data were analyzed by least squares ANOVA using the proc GLM and MIXED models of the SAS package and were tested for normality for each variable (ShapiroWilk test) and homogeneity of variances ( $F$ test maximum). Data were log-transformed when they didn't obey the premises for the analysis of variance (PGFM at zero moment - progesterone $<1 \mathrm{ng} / \mathrm{mL}$; PGFM before the drop in progesterone level; PGFM after the drop in progesterone level; minimum PGFM in each animal and plasma concentration of PGFM throughout the time). For the sake of clarity, it was presented as untransformed least square means \pm S.E. Maximum PGFM in each animal, luteolysis day, PGFM during the evaluated period and plasma progesterone concentration throughout the time were analyzed without transformation. Effects of cow, treatment, time and all interactions were analyzed.

Mean and standard error (mean \pm S.E.) were measured for all analyzed variables, and also to calculate the PGFM at the peak moment for both evaluated groups. The means were separated by orthogonal contrasts (Control Group vs. Biopsy Group).

\section{RESULTS}

The results are presented in Table 1, Figures 1 and 2. It was found that the average value (mean \pm SE) for PGFM during the whole period was greater in the biopsy group compared with $\begin{array}{lll}\text { controls } \quad(81.9 \pm 10.8 \quad \text { vs } & 51.1 \pm 9.8 \mathrm{pg} / \mathrm{mL}\end{array}$ respectively, $\mathrm{P}<0.05)$. Although the average concentration of PGFM at time zero (progesterone drop $<1 \mathrm{ng} / \mathrm{mL}$ ) was not different between the biopsy and control groups $(53.3 \pm 13.5$ vs $\quad 66.3 \pm 14.6 \mathrm{pg} / \mathrm{mL}$ respectively, $\mathrm{P}>0.05$ ), mean concentration of PGFM was different between the biopsy and control groups before the fall of progesterone concentration $(83.4 \pm 16.3$ vs $55.4 \pm 16.4 \mathrm{pg} / \mathrm{mL}$ respectively, $\mathrm{P}<0.05)$ and after the fall $(98.3 \pm 19.7 \quad v s$ $41.4 \pm 8.5 \mathrm{pg} / \mathrm{mL}$ respectively, $\mathrm{P}<0.01)$. The mean maximum level was not different between the biopsy and control groups $(186.4 \pm 30.7$ vs $112.6 \pm 21.0 \mathrm{pg} / \mathrm{mL}$ respectively, $\mathrm{p}=0.08$ ), while the average minimum concentration was higher in the biopsy group compared with controls $(28.4 \pm 6.7$ vs $12.4 \pm 2.8 \mathrm{pg} / \mathrm{mL}$ respectively, $\mathrm{P}<0.01)$. On the day of luteolysis, there was no difference between the biopsy and control groups $(18.3 \pm 1.0$ vs $18.3 \pm 0.6 \mathrm{pg} / \mathrm{mL}$ days respectively, $\mathrm{P}=0.2$ ) and the estrous cycle length was also similar between the groups $(23.69 \pm 0.49$, control group vs $23.64 \pm 0.86$, biopsy group, $\mathrm{P}>0.05$ ). 
Table 1. Mean and standard error (mean \pm SE) of plasma PGFM values obtained by radioimunoassay from Nelore cows submitted or not to uterine biopsy sample collection throughout the estrous cycle

\begin{tabular}{lcc}
\hline Variables & $\begin{array}{c}\text { Biopsy Group } \\
\mathrm{N}=14\end{array}$ & $\begin{array}{c}\text { Control Group } \\
\mathrm{N}=15\end{array}$ \\
\hline Mean PGFM $(\mathrm{pg} / \mathrm{mL})$ concentration during the evaluated period & $81.9 \pm 10.8^{\mathrm{a}}$ & $51.1 \pm 9.8^{\mathrm{b}}$ \\
Mean concentration of PGFM $(\mathrm{pg} / \mathrm{mL})$ on moment zero $(\mathrm{P} 4<1 \mathrm{ng} / \mathrm{mL})$ & $53.3 \pm 13.5$ & $66.3 \pm 14.6$ \\
Mean concentration of PGFM $(\mathrm{pg} / \mathrm{mL})$ before the drop in progesterone & $83.4 \pm 16.3^{\mathrm{a}}$ & $55.4 \pm 16.4^{\mathrm{b}}$ \\
level & & \\
Mean concentration of PGFM $(\mathrm{pg} / \mathrm{mL})$ after the drop in progesterone & $98.3 \pm 19.7^{\mathrm{a}}$ & $41.4 \pm 8.5^{\mathrm{b}}$ \\
level & $186.4 \pm 30.7$ & $112.6 \pm 21.0$ \\
Maximum mean concentration of PGFM $(\mathrm{pg} / \mathrm{mL})$ & $28.4 \pm 6.7^{\mathrm{a}}$ & $12.41 \pm 2.8^{\mathrm{b}}$ \\
Minimum mean concentration of PGFM $(\mathrm{pg} / \mathrm{mL})$ & $18.29 \pm 1.00$ & $18.33 \pm 0.63$ \\
\hline Luteolysis day & & \\
\hline Means followed by different letters are significantly different $(\mathrm{P}<0.05)$ &
\end{tabular}

Means followed by different letters are significantly different $(\mathrm{P} \leq 0.05)$

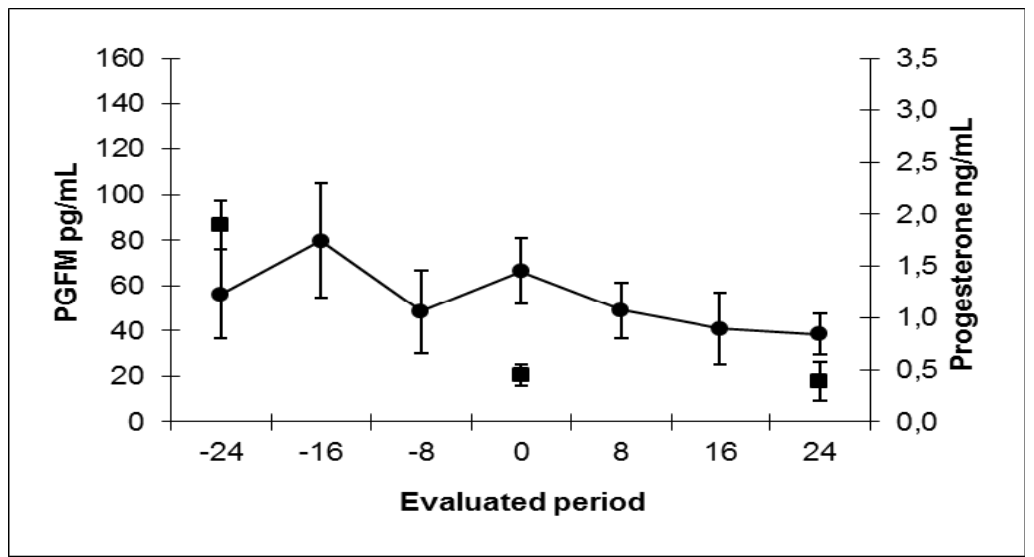

Figure 1. Mean plasma concentrations (mean \pm SE) of PGFM $(\bullet, \mathrm{pg} / \mathrm{mL})$ and progesterone $(\boldsymbol{\bullet}, \mathrm{ng} / \mathrm{mL})$ obtained by radioimmunoassay during the evaluated period in Nelore cows not subjected to uterine biopsy sample collection throughout the estrous cycle (Control Group).

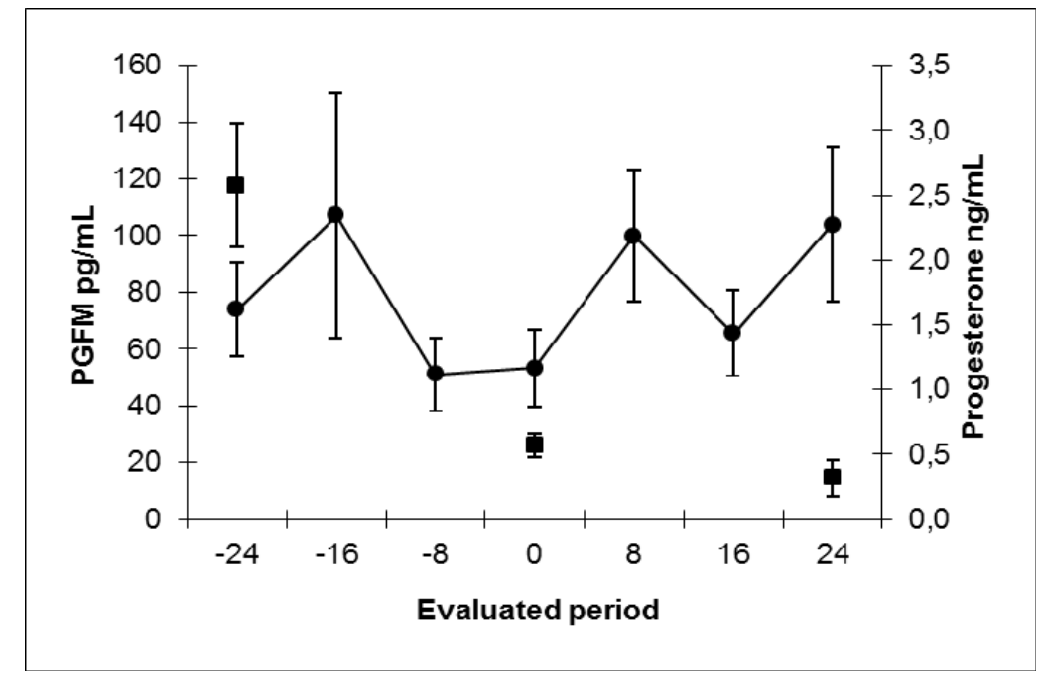

Figure 2. Mean plasma concentrations (mean \pm SE) of PGFM $(\bullet, \mathrm{pg} / \mathrm{mL})$ and progesterone $(\boldsymbol{\bullet}, \mathrm{ng} / \mathrm{mL})$ obtained by radioimmunoassay during the evaluated period in Nelore cows subjected to uterine biopsy sample collection throughout the estrous cycle (Biopsy Group). 


\section{DISCUSSION}

In this study, luteolysis was observed on day 18 of the estrous cycle in both groups, as reported in the literature (Okuda et al., 2002; Ginther et al., 2009). The interovulatory interval observed in the present study was similar to data reported earlier in Nelore cows with two and three waves of follicular growth, $20.65 \pm 0.46$ and $22.0 \pm 0.44$, respectively (Figueiredo et al., 1997), for zebu cows, 21.0 \pm 3 days (Ruiz-Cortés and OliveiraAngel 1999) and for gir cows, 21.11 \pm 1.76 and $22.65 \pm 1.71$, with three and four follicular waves, respectively (Viana et al., 2000).

Although few blood samples were collected, it was evident from our study that the release of PGFM occurs in pulses in Nelore cows, as described in the literature (Okuda et al., 2002; Ginther et al., 2009).

In the present study, PGFM pulses were coincident with the fall in progesterone concentrations, as reported in the literature (Kindahl et al., 1976; Mann and Lamming 2006) and the mean values of PGFM observed in the luteal phase were similar to values reported before. However, the average values of PGFM related to the event of luteolysis were lower than reported data (Kindahl et al., 1976; Kotwica et al., 1998) for both groups and animals in the biopsy group had PGFM values that were occasionally higher than that observed for the control group and similar to that described in the literature as depicted in the maximum mean concentration of PGFM in table 1.

In the current study, a higher concentration of PGFM was observed in animals subjected to endometrial biopsy which differs from the study of Mann and Lamming (1994), where the collection of biopsies at two-day intervals between days 13 and 17 after estrus did not induce any release of PGF2 $\alpha$. Nevertheless, both studies agree when the length of the estrous cycle is considered. In both studies the biopsies procedures did not shorten the length of the estrous cycle. This difference could be related to the number of biopsies collected and to the collection of endometrial samples throughout the entire estrous cycle, which could favor local inflammatory responses that could elevate the plasma PGFM concentrations, but not enough to alter the length of the estrous cycle.
The process of endometritis is characterized by congestion of the mucosa and prominent leukocyte infiltration with the presence or absence of discharge from the vagina (Mateus et al., 2003). According to these same authors, plasma PGFM concentrations were significantly higher in cows with severe than with mild endometritis, which suggests that the plasma concentrations of PGFM are related to the degree of endometritis. Other authors (Del Vecchio et al., 1992; Del Vecchio et al., 1994) observed that cows with endometritis had significantly higher plasma PGFM concentrations than that of control uninfected cows. These data indicate that uterine infections increase peripheral PGFM concentrations and suggest a potential use of PGFM measurement as an indicator of uterine infection. In the present study, we found that mean plasma concentrations of PGFM were higher in the biopsy group, which could be related to an inflammatory process of the endometrium.

According to a study reported previously by our group (Maziero et al., 2013), the presence of bloody mucus is usually observed after the removal of the biopsy nippers, and a discrete mucopurulent discharge was observed in four animals, but with normal cyclicity. The occurrence of purulent discharge was observed in only one animal, which presented enlarged uterine horns and acyclicity. When the cellularity of the samples was evaluated, the occurrence of mononuclear infiltrate didn't change throughout the estrous cycle, and the presence of these cells is probably not related with the biopsy. However, the polymorphonuclear infiltrate enhanced significantly throughout the estrous cycle with maximum values observed on day 13 .

The release of PGFM throughout the estrous cycle was not enough to shorten the estrous cycle in biopsy group, which could be related to our biopsy collection method. The collection of endometrial tissue in the uterine horn contralateral to the ovary containing the corpus luteum could be responsible for the local release of endometrial PGF $2 \alpha$ in that horn, but PGF2 $\alpha$ may not reach the contra-lateral horn. It has been postulated that PGF $2 \alpha$ enters the ovarian artery from the utero-ovarian vein, via a countercurrent exchange mechanism, which allows PGF $2 \alpha$ to travel to the ovarian artery without making it to the pulmonary circulation where it would be 
enzymatically inactivated in the lungs (Piper et al., 1970). This hypothesis is supported by reports done in studies involving partial hysterectomy and vascular anastomosis studies, where it was possible to observe that initiation of luteolysis by PGF $2 \alpha$ in many species appears to be a local effect between each uterine horn and its ipsilateral ovary (Del Campo and Ginther, 1974).

Thus, it became clear that the endometrial biopsy increases the release of PGFM, however, this was not enough to anticipate luteolysis in females subjected to endometrial biopsy in the uterine horn contra-lateral to the ovary containing the corpus luteum.

\section{CONCLUSIONS}

In conclusion, the obtained results showed that repeated endometrial biopsies did not result in any shortening of the length of the estrous cycle. Otherwise, this technique induces the release of prostaglandin $F 2 \alpha$, which was measured by higher concentrations of PGFM in the biopsy group.

\section{ACKNOWLEDGMENTS}

The authors thank Sao Paulo Research Foundation (FAPESP) for their financial support.

\section{REFERENCES}

BARROS, C.M.; MOREIRA, M.B.P.; FIGUEIREDO, R.A. et al. Synchronization of ovulation in beef cows (Bos indicus) using GnRH, PF $2 \alpha$ and estradiol benzoate. Theriogenology, v.53, p.1121-1134, 2000.

CHAPWANYA, A.; MEADE, K.G.; NARCIANDI, F. et al. Endometrial biopsy: a valuable clinical and research tool in bovine reproduction. Theriogenology, v.73, p.988-994, 2010.

DEL CAMPO, C.H.; GINTHER, O.J. Vascular anatomy of uterus and ovaries and the unilateral luteolytic effect of the uterus: histological structure of uteroovarian vein and ovarian artery in sheep. Am. J. Vet. Res., v.35, p.397-399, 1974.
DEL VECCHIO, R.P.; MATSAS, D.J.; FORTIN, S. et al. Spontaneous uterine infections are associated with elevated prostaglandin $F_{2} \alpha$ metabolite concentrations in postpartum dairy cows. Theriogenology, v.41, p.413-421, 1994.

DEL VECCHIO, R.P.; MATSAS, D.J.; INZANA, T.J. et al. Effect of intrauterine bacterial infusions and subsequent endometritis on prostaglandin F2 alpha metabolite concentrations in postpartum beef cows. J. Anim. Sci., v.70, p.3158-3162, 1992.

FIGUEIREDO, R.A.; BARROS, C.M.; PINHEIRO, O.L. et al. Ovarian follicular dynamics in Nelore breed (Bos indicus) cattle. Theriogenology, v.47, p.1489-1505, 1997.

GINTHER, O.J.; ARAUJO, R.R.; PALHÃO, M.P. et al. Necessity of sequential pulses of prostaglandin F2alpha for complete physiologic luteolysis in cattle. Biol. Reprod., v.80, p.641648, 2009.

GINTHER, O.J.; SILVA, L.A.; ARAUJO, R.R. et al. Temporal associations pulses of 13,14Dihydro-15-keto-PGF2alpha, luteal blood flow, and luteolysis in cattle. Biol. Reprod., v.76, p.506-513, 2007.

GOFF, A.K. Steroid hormone modulation of prostaglandin secretion in the ruminant endometrium during the estrous cycle. Biol. Reprod., v.71, p.11-16, 2004.

GRANSTRÖM, E.; SAMUELSSON, B. Quantitative measurement of prostaglandins and thromboxanes: general considerations. Adv. Prostaglandin Thromboxane Res., v.5, p.1-13, 1978.

HOMANICS, G.E.; SILVIA, W.J. Effects of progesterone and estradiol-17 beta on uterine secretion of prostaglandin F2 alpha in response to oxytocin in ovariectomized ewes. Biol. Reprod., v.38, p.804-811, 1988.

KINDAHL, H.; BASU, S.; FREDIKSSON, G. et al. Levels of prostaglandin F2 $\alpha$ metabolites in blood and urine during early pregnancy. Anim. Reprod. Sci., v.7, p.133-148, 1984.

KINDAHL, H.; EDQVIST, L.E.; GRANSTROM, E. et al. The release of prostaglandin F2 $\alpha$ as reflected by 15 -keto-13,14dihydroprostaglandin $\mathrm{F} 2 \alpha$ in the peripheral circulation during normal luteolysis in heifers. Prostaglandins, v.11, p.871-878, 1976. 
KOTWICA, J.; SKARZINSKY, D.; JAROSZEWSKI, J. et al. Uterine secretion of prostaglandin F2 $\alpha$ stimulated by different doses of oxytocin and released spontaneously during luteolysis in cattle. Reprod. Nutr. Dev., v.38, p.217-226, 1998.

MANN, G.E.; LAMMING, G.E. Timing of prostaglandin $\mathrm{F} 2 \alpha$ release episodes and oxytocin receptor development during luteolysis in the cow. Anim. Reprod. Sci., v.93, p.328-336, 2006.

MANN, G.E.; LAMMING, G.E. Use of repeated biopsies to monitor endometrial oxytocin receptors in the cow. Vet. Rec., v.135, p.403-405, 1994.

MANN, G.E.; ROBINSON, R.S.; WATHES, D.C. et al. The regulation of interferon-tau production and uterine hormone receptors during early pregnancy. J. Reprod. Fertil. Suppl., v.54, p.317-328, 1999.

MANSPEAKER, J.E.; BOIS, C.H.W. Endometrial biopsy of the bovine. In: MORROW, D.A. (Ed). Current therapy in theriogenology: diagnosis, treatment and prevention of reproductive diseases in small and large animals. 2.ed. Philadelphia: Saunders, 1986. p.424-426.

MATEUS, L.; LOPES DA COSTA, L.; DINIZ, P. et al. Relationship between endotoxin and prostaglandin (PGE2 and PGFM) concentrations and ovarian function in dairy cows with puerperal endometritis. Anim. Reprod. Sci., v.76, p.143-154, 2003.

MAZIERO, R.R.D.; MATTOS, M.C.C.; TEIXEIRA, L.B.C. et al. Biopsias endometriais seriadas em vacas Nelore (Bos taurus indicus) durante o ciclo estral. Rev. Bras. Reprod. Anim., v.37, p.371376, 2013.
MISHRA, D.P.; MEYER, H.H.D.; PRAKASH, B.S. Validation of a sensitive enzymeimmunoassay for 13,14-dihydro-15-keto-PGF ${ }_{2 \alpha}$ in buffalo plasma and its application for reproductive health status monitoring. Anim. Reprod. Sci., v.78, p.3346, 2003.

MIYAMOTO, A.; SHIRASUNA, K.; WIJAYAGUNAWARDANE, M.P.B. et al. Blood flow: a key regulatory component of corpus luteum function in the cow. Dom. Anim. Endocrinol., v.29, p.329-339, 2005.

OKUDA, K.; MIYAMOTO, Y.; SKARZYNSKI, D.J. Regulation of endometrial prostaglandin F2 $\alpha$ synthesis during luteolysis and early pregnancy in cattle. Dom. Anim. Endocrinol., v.23, p.255-264, 2002.

PIPER, P.J.; VANE, J.R.; WYLLIE, J.H. Inactivation of prostaglandins by the lungs. Nature, v.225, p.600-604, 1970.

RUIZ-CORTÉS, Z.T.; OLIVEIRA-ANGEL, M. Ovarian follicular dynamics in suckled zebu (Bos indicus) cows monitored by real time ultrasonography. Anim. Reprod. Sci., v.54, p.211-220, 1999.

SHIRASUNA, K.; ASAOKA, H.; ACOSTA, T.J. et al. Real-time dynamics of prostaglandin F $2 \alpha$ release from uterus and corpus luteum during spontaneous luteolysis in the cow. Reproduction, v.128, p.189-195, 2004.

SILVIA, W.J.; LEWIS, G.S.; MCCRACKEN, J.A. et al. Hormonal regulation of uterine secretion of prostaglandin F2 alpha during luteolysis in ruminants. Biol. Reprod., v.45, p.655-663, 1991.

VIANA, J.H.M.; FERREIRA, A.M.; SÁ, W.F. Follicular dynamics in zebu cattle. Pesqui. Agropecu. Bras., v.35, p.2501-2509, 2000. 